\title{
Cryptocotyle lata (Trematoda: Heterophyidae) Adult from a Korean Raccoon Dog, Nyctereutes procyonoides koreensis
}

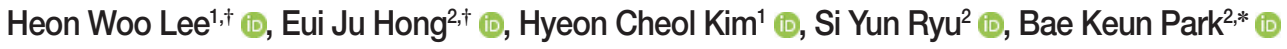 \\ ${ }^{1}$ College of Veterinary Medicine and Institute of Veterinary Science, Kangwon National University, Chuncheon 24341, Korea; \\ ${ }^{2}$ College of Veterinary Medicine, Chungnam National University, Daejeon 34134, Korea
}

\begin{abstract}
Total 513 heterophyid flukes were collected from a carcass of wild Korean raccoon dog, Nyctereutes procyonoides koreensis, in Korea. With morphological and molecular characteristics, the flukes were identified to Cryptocotyle lata. The adult $C$. lata were minute, transparent, pentagonal, $522 \mu \mathrm{m}$ long by $425 \mu \mathrm{m}$ wide. Ceca extended into post-testicular region. Ventrogenital sac elliptical, $79 \mu \mathrm{m}$ by $87 \mu \mathrm{m}$ with genital pore and ventral sucker. Two testes semielliptical and slightly lobed, located in the posterior region, right testis $173 \mu \mathrm{m}$ by $155 \mu \mathrm{m}$, left testis $130 \mu \mathrm{m}$ by $134 \mu \mathrm{m}$. In a phylogenetic tree, the fluke specimen of this study was grouped with $C$. lata divergent from Cryptocotyle lingua. We report here $N$. procyonoides koreensis first as a natural definitive host of $C$. lata.
\end{abstract}

Key words: Cryptocotyle lata, Nyctereutes procyonoides koreensis, Korean raccoon dog, natural definitive host, Korea

The family Heterophyidae contains a number of intestinal trematodes that can be found in various vertebrates including birds and mammals and they also have potential of zoonosis [1]. In the Republic of Korea (Korea), more than 14 species of heterophyid flukes, i.e., Metagonimus spp., Heterophyes nocens, Pygidiopsis summa, Heterophyopsis continua, Stictodora fuscata, Stictodora lari, Acanthotrema felis, Stellantchasmus falcatus, Centrocestus armatus, Procerovum varium, Cryptocotyle sp., Cryptocotyle concava and Euryhelmis squamula, were reported from carnivore (feral or stray cat and raccoon dog) [2-5]. Of these heterophyid flukes, members of genus Cryptocotyle are mainly developed in the intestines of fish-eating birds and mammals as adult worms [6-9].

Fluke members in the genus Cryptocotyle are mainly divided into 2 types, i.e., linguiform and pentagonal or ovoid form, by the body shape. A total of 4 species, i.e., C. dominicana, C. jejuna, C. lingua and C. thapari, were described as the linguiform species [6,10-15]. As the pentagonal or ovoid form species, more than 9 ones, i.e., C. concava, C. cryptocotyloides, C. quin-

\footnotetext{
- Received 22 September 2021, revised 22 November 2021 , accepted 22 November 2021

*Corresponding author (bkpark@cnu.ac.kr)

† These authors contributed equally to this work.

(C) 2021, Korean Society for Parasitology and Tropical Medicine

This is an Open Access article distributed under the terms of the Creative Commons Attribution Non-Commercial License (https://creativecommons.org/licenses/by-nc/4.0) which permits unrestricted non-commercial use, distribution, and reproduction in any medium, provided the original work is properly cited.
}

queangularis, C. badamshini, C. delamurei, C. misgurni, C. gyrinicola, C. yamashitai and C. lata, were recorded in the literatures [5,8,10,15-24].

Recently, Tatonova and Besprozvannykh described a new species of genus Cryptocotyle, C. lata n. sp. [24]. They recovered adult worms from domestic duck, Anas platyrhynchos, which were experimentally infected with metacercariae collected from the second intermediate hosts, Rhynchocypris percnurus mantschuricus and Rana dybowskii, in Russia [24]. However, the natural definitive hosts of $C$. lata have not been reported yet.

A wild raccoon dog was found in Hyoja-dong (dong=

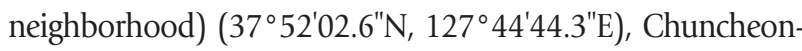
si (si=City), Gangwon-do (do= Province), Korea in May 2015. The rescued raccoon dog was moved to the Gangwon Wildlife Medical Rescue Center (WMRC) at Kangwon National University, and found dead at WMRC in the next day (May 15, 2015). A total of 513 trematode worms were recovered from the small intestines of the raccoon dog. For the morphological study, we photographed the flukes before and after fixation with 70\% alcohol. A typical image was created using tracing paper. All measurements $(n=10)$ are presented as arithmetic mean (range) in micrometer $(\mu \mathrm{m})$.

Genomic DNA was extracted from the flukes using the DNeasy ${ }^{\circledR}$ Blood and Tissue Kit (Qiagen, Alameda, California, USA) according to the manufacturer's instructions. Based on the $18 \mathrm{~S}$ ribosomal RNA gene sequences of Euryhelmis costari- 
censis (AB5217897), primers were designed using the online tool Primer3Plus (http://www.bioinformatics.nl/cgi-bin/primer3plus/primer3plus.cgi). The sequences of primers employed to detect the18S rRNA gene (DNA) of Cryptocotyle specimens were as follows: 5'-TGCCTTATCCCAGGTACGAC-3' (forward primer) and 5'-CAGTTCAACTCCACCCGTTT-3' (reverse primer). The primer set was designed to yield 979 bp amplicon. The reaction mix was prepared with EmeraldAmp GT PCR Master Mix (Takara, Shiga, Japan) and $1 \mu$ of the fluke's DNA aliquot. PCR was performed using MyCycler Personal Thermal Cycler (Bio-Rad Laboratories, Hercules, California, USA).PCR was performed under standard condition with 30-35 cycles of $95^{\circ} \mathrm{C}$ for $30 \mathrm{sec}$, annealing at $60^{\circ} \mathrm{C}$ for $30 \mathrm{sec}$, and extension at $72^{\circ} \mathrm{C}$ for $1 \mathrm{~min}$. The PCR amplicons were electrophorezed on $1.2 \%$ agarose gel, and the target DNA bands were purified using the QIAquick PCR Purification Kit (Qiagen, Alameda, California, USA). The PCR amplicons were directly sequenced using the ABI Prism Big Dye terminator v. 3.0 ready reaction cycle sequencing kits (Applied Biosystems, Foster City, California, USA) and the PCR primers. After trimming, the amplicon revealed 784 bp sequence, and aligned using Clustal Omega program (Clustal O, EMBL-EBI, Hinxton, Cambridgeshire, United Kingdom). A phylogenetic tree was constructed with homologous sequences retrieved from NCBI by using neighbor-joining (NI) method [25].
The morphological characters of total 513 heterophyid flukes in this study were as follow (Fig. 1). Body small, transparent, pentagonal, 522 (339-646) $\mu \mathrm{m}$ long and 425 (300493) $\mu \mathrm{m}$ wide. Oral sucker subterminal, 59 (52-65) $\mu \mathrm{m}$ by 66 (53-71) $\mu \mathrm{m}$. Pharynx large, spherical, 56 (38-61) $\mu \mathrm{m}$ by 47 (43-49) $\mu \mathrm{m}$. Esophagus slender, straight, long, 87 (79-96) $\mu \mathrm{m}$ in length (Fig. 1B). Ceca extended into post-testicular region. Ventrogenital sac elliptical, 79 (71-88) $\mu \mathrm{m}$ by 87 (83-91) $\mu \mathrm{m}$ with genital pore and ventral sucker. Seminal vesicle saccate, 98 (59-121) $\mu \mathrm{m}$ by 185 (117-205) $\mu \mathrm{m}$. Ovary spherical, 128 (86-148) $\mu \mathrm{m}$ by 164 (109-180) $\mu \mathrm{m}$, lying dextral to median line. Seminal receptacle elliptical and large, 89 (68-118) $\mu \mathrm{m}$ by 95 (77-131) $\mu \mathrm{m}$, just behind of the left margin of ovary. Two testes semielliptical and slightly lobed, located pararelly in the posterior region, right testis 173 (168-190) $\mu \mathrm{m}$ by 155 (150157) $\mu \mathrm{m}$, left testis 130 (110-145) $\mu \mathrm{m}$ by 134 (120-147) $\mu \mathrm{m}$. Vitellaria follicular along mainly extra-cecal margin from posterior bifurcation of the intestinal ceca to posterior end of body. Uterus passed transversally from left to right, then from right to left in field surrounded by ventrogenital sac, ceca and gonads, containing 10-45 eggs. Eggs operculated, with slight polar thickening, undeveloped when laid, and 35 (32-37) $\mu \mathrm{m}$ by $18(17-20) \mu \mathrm{m}$. These morphological characteristics implied the minute heterophyid flukes to be $C$. lata.

To determine the phylogenetic relationship with other para-
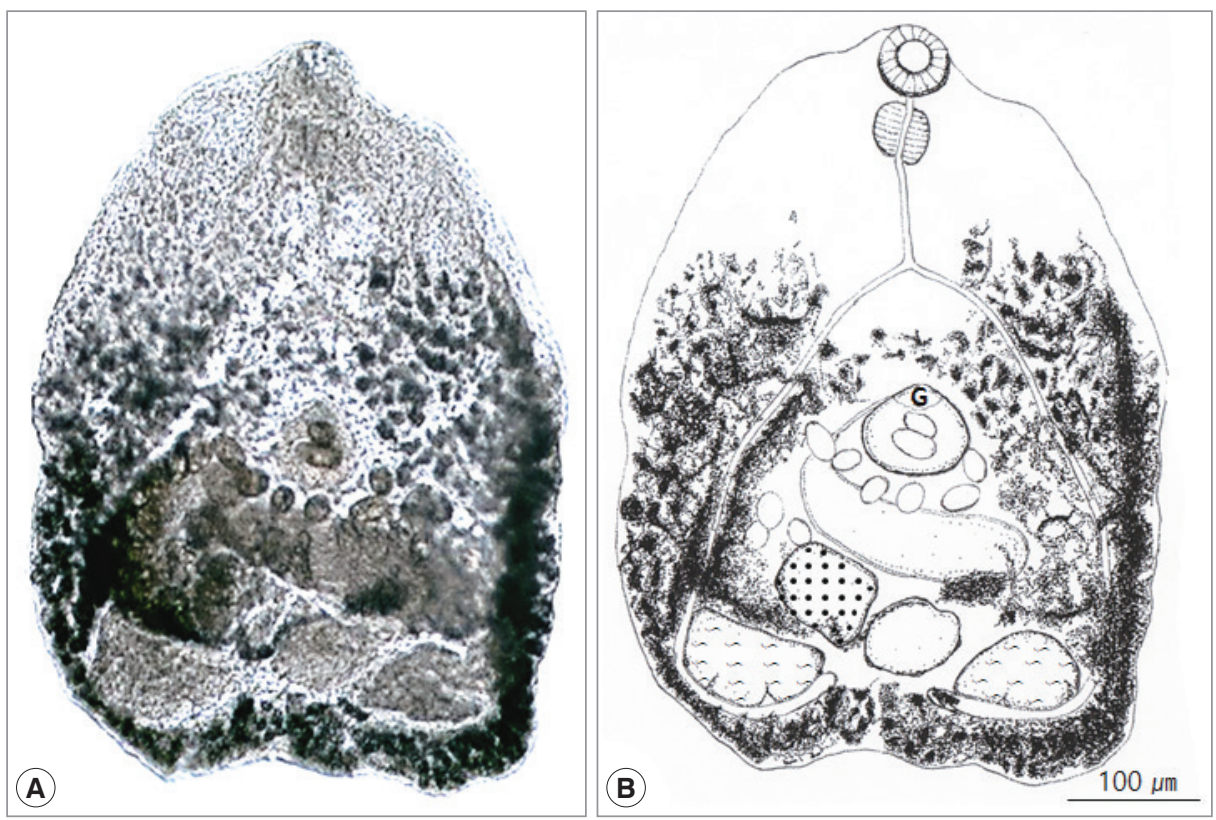

Fig. 1. Cryptocotyle lata adult recovered from the small intestine of a Korean raccoon dog. (A) Unstained fluke. (B) Schematic drawing. $\mathrm{G}$, ventrogenital sac. 
sites, we analyzed the genomic DNA of the specimens using phylogenetic analysis. The partial sequence of $18 \mathrm{~S}$ rRNA of Cryptocotyle specimens was registered into GenBank under an accession number (MZ436998.1) for Cryptocotyle specimens. The sequencing information was compared to those of other parasites, including E. costaricensis (AB521800.1), Euryhelmis zelleri (KM594133.1) and C. lingua (MW361240.1). The partial $18 \mathrm{~S}$ rRNA sequence (784 bp) of the Cryptocotyle specimens contained 1 variable point ( $99 \%$ similarity) that belonged to the same clade of $C$. lata. The $18 \mathrm{~S}$ rRNA sequence of Cryptocotyle specimens was inferred using the $\mathrm{NJ}$ method. The Cryptocotyle specimen showed high similarity (97\%) to C. lingua (Fig. 2). The sequence of Cryptocotyle specimen was closely grouped with C. lata divergent from C. lingua. Based on these morphological characteristics and phylogenetic features, our Cryptocotyle specimen (MZ436998.1) was identified to C. lata.

The species of the genus Cryptocotyle are world-widely distributed in the marine and freshwater environment [6]. Although the literature on the life cycle of Cryptocotyle species is scarce, snails and fish are known as first and second intermediate hosts, respectively. And the definitive hosts for Cryptocotyle spp. are also known as fish-eating birds and mammals [8,9,
17].

As far as we know, the species known only from mammals are C. badamshini from Caspian seals [20], C. delamurei from Commander fur seal [21], C. quinqueangularis from cat [15], C. yamashitai from red fox [23], and C. thapari from River Otter [15]. Only two, C. cryptocotyloides has been reported only from birds (the arctic loon, Gavia arctica) in Russia [18] and C. dominicana from Kelp gull [6]. Four species are known from both birds and mammals; $C$. concava from many different birds and mammals $[5,10,15-17,26]$; C. jejuna from gulls and dogs $[11,12,15]$; C. lingua primarily from marine birds, marine mammals, dogs, cats, and Rattus [12,15]. Among them, C. concava of carnivorous mammals such as feral cats and raccoons and C. lingua of Larus argentatus, a herring gull, have been reported by former researchers in Korea $[2,3,27]$. On the other hand, there are some species whose natural final host is unknown. Adults of C. gyrinicola were obtained experimentally by feeding cats and pigeons with metacercariae from tadpoles [22], and adults of C. misgurni were obtained experimentally by feeding golden hamsters with metacercariae encysted in loaches [8]. Adults of $C$. lata were obtained experimentally by feeding ducklings with metacercariae encysted in tadpoles and

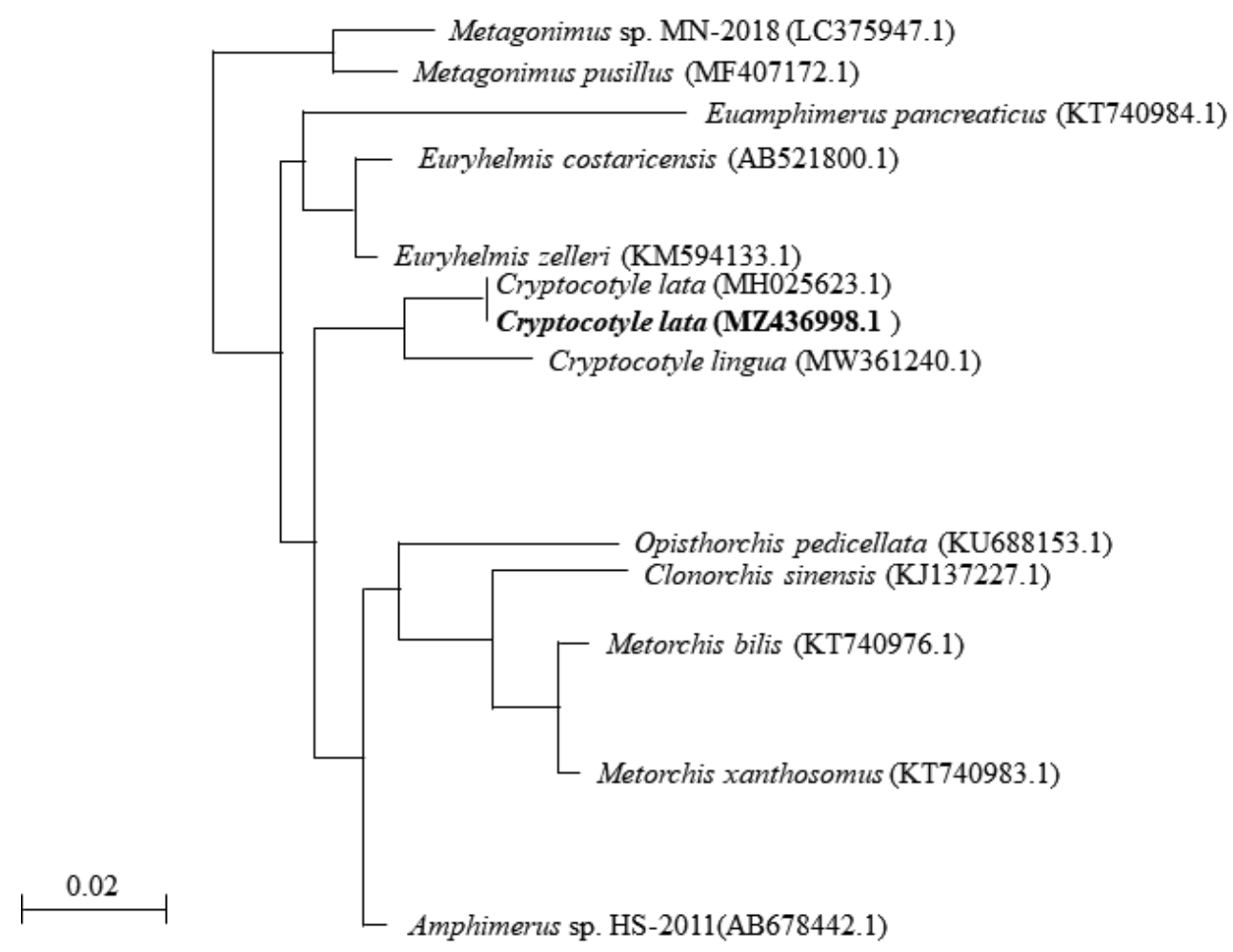

Fig. 2. A phylogenetic tree based on Cryptocotyle lata 18S rRNA sequences. 


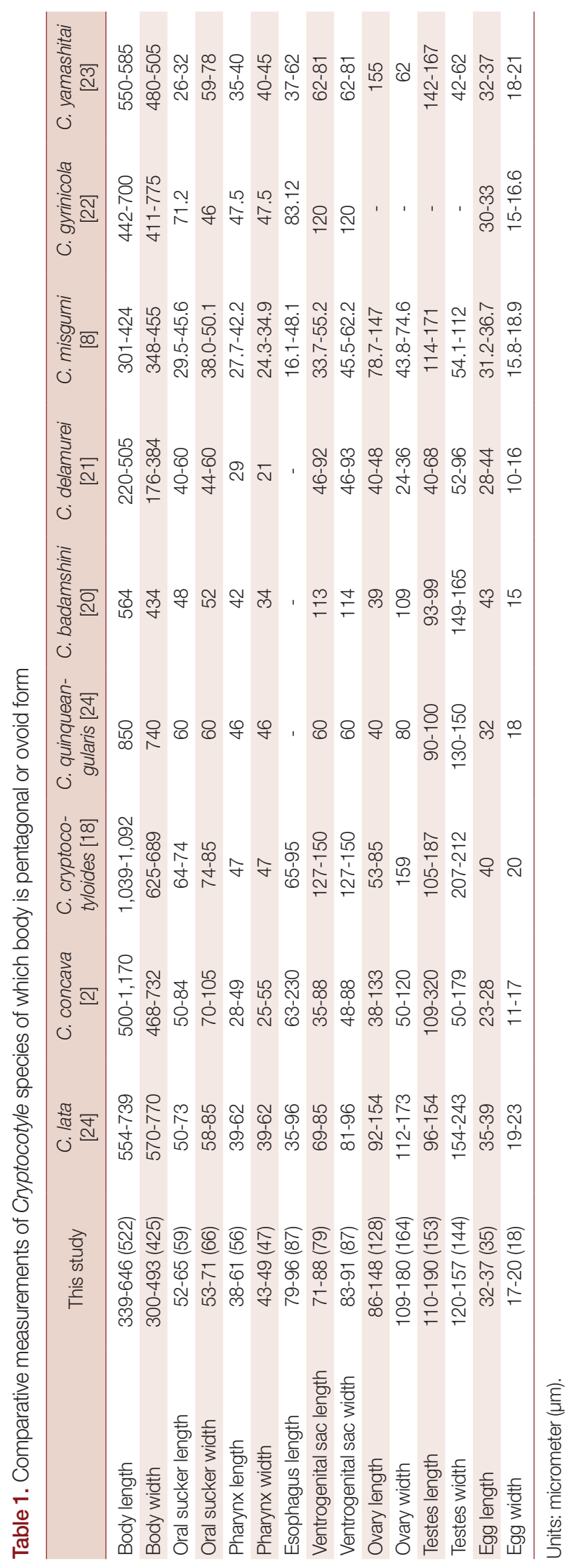

fish [24]. We also reported a heterophyid fluke, E. squamula, similar to C. lata from a Korean raccoon dog in 2021 [5]. The morphological characteristic of E. squamula is different from other heterophyid flukes in body having rectangular and broader than length. In the present study, the fluke observed in Korean raccoon dog was identified as C. lata. This is the first record as the natural definitive host of this parasite.

There are 13 species of genus Cryptocotyle worldwide and the species have two form of body shape: linguiform and pentagonal or ovoid form. When identifying the specimen of the present study, we only compared it with 9 species having pentagonal or ovoid form, excluding 4 species which have linguiform: C. lingua, C. jejuna, C. thapari, C. dominicana. In this study, the body length measured in 522 (339-646) $\mu \mathrm{m}$, so we also excluded pentagonal or ovoid form species having difference in body length with the specimen; C. concava 500-1,170 $\mu \mathrm{m}, \mathrm{C}$. quinqueangularis $850 \mu \mathrm{m}$, C. cryptocotyloides 1,039-1,092 $\mu \mathrm{m}$ (Table 1). C. badamshini and C. delamureis had much smaller ovaries, and C. misgurni and C. gyrinicola had significantly different body length and width ratios from those of this study. There are few morphological differences between C. yamashitai and $C$. lata, except for very small differences. However, the genetic information of C. yamashitai is not available. It is impossible to compare phylogenetic similarity of them now.

In this study, the genetic divergence of the Cryptocotyle specimens revealed their conspecific relationship with $C$. lingua and exact correspondence with C. lata.

Conclusively, it was confirmed for the first time that based on the morphological and molecular characteristics, C. lata indigenously infected the Korean raccoon dog, N. procyonoides koreensis in Korea. Additional life cycle studies on the intermediate hosts and other natural definitive hosts of this fluke should be performed in near future in Korea.

\section{ACKNOWLEDGMENT}

This research was supported by Basic Science Research Program through the National Research Foundation of Korea (NRF) funded by the Ministry of Education (Grant No. 2017 RIDIAIB06031728).

\section{CONFLICT OF INTEREST}

The authors declare no conflict of interest related to this study. 


\section{REFERENCES}

1. Santos CP, Borges JN. Current knowledge of small flukes (Digenea: Heterophyidae) from South America. Korean J Parasitol 2020; 58: 373-386. https://doi.org/10.3347/kjp.2020.58.4.373

2. Chai JY, Bahk YY, Sohn WM. Trematodes recovered in the small intestine of stray cats in the Republic of Korea. Korean J Parasitol 2013; 51: 99-106. https://doi.org/10.3347/kjp.2013.51.1.99

3. Sohn WM, Chai JY. Infection status with helminthes in feral cats purchased from a market in Busan, Republic of Korea. Korean J Parasitol 2005; 43: 93-100. https://doi.org/10.3347/kjp.2005.43.3.93

4. Shin EH, Park JH, Guk SM, Kim JL, Chai JY. Intestinal helminth infections in feral cats and a raccoon dog on Aphaedo Island, Shinangun, with a special note on Gymnophalloides seoi infection in cats. Korean J Parasitol 2009; 47: 189-191. https://doi.org/10.3347/ kjp.2009.47.2.189

5. Kim HC, Hong EJ, Ryu SY, PJ, Cho JG, Yu DH, Chae JS, Choi KS, Park BK. Euryhelmis squamula (Digenea: Heterophyidae) recovered from Korean raccoon dog, Nyctereutes procyonoides koreensis, in Korea. Korean J Parasitol 2021; 59: 303-309. https://doi.org/10.3347/ kjp.2021.59.3.303

6. Yamaguti S. A synopsis of digenetic trematodes of vertebrates. Vol. I. Keigaku Publishing Co. Tokyo, Japan. 1971, pp 1074.

7. Casalins LM, Arbetman MP, Viozzi GP, Flores VR. A new species of Cryptocotyle (Eigenea: Heterophyidae) infecting kelp gull and a galaxiid fish in Patagonian freshwater environments: morphological and molecular analyses. J Parasitol 2020: 106: 203-210. https://doi.org/10.1645/18-44

8. Ohyama F, Okino T, Ushirogawa H. Massaliatrema misgurni n. sp. (Trematoda: Heterophyidae) whose metacercariae encyst in loaches (Misgurnus anguillicaudatus). Parasitol Int 2001; 50: $267-$ 271. https://doi.org/10.1016/S1383-5769(01)00084-8

9. Pearson J. Family heterophyidae leiper, 1909. In Bray R, Gibson D, Jones A eds, In Keys to the Trematoda, Vol. 3. CAB International and Natural History Museum. London, UK. 2008, pp 113-141.

10. Ransom BH. Synopsis of the trematode family Heterophyidae with descriptions of a new genus and five new species. Pro U S Natl Mus 1920; 57: 527-573. https://doi.org/10.5479/si.00963801.572322.527

11. Rothschild M. Preliminary note on the life-history of Cryptocotyle jejuna Nicoll, 1907 (Trematoda). Ann Mag Nat Hist 1938; 1: 238-239. https://doi.org/10.1080/00222933808526760

12. Nicoll W. Observations on the trematode parasites of British birds. Ann Mag Nat Hist 1907; 20: 245-271. https://doi.org/10.1080/ 00222930709487332

13. Stunkard HW. Life history of Cryptocotyle lingua (Creplin) from the gull and tern. J Morph Physiol 1930; 50: 143-191. https:// doi.org/10.1002/jmor.1050500106

14. Kitamura Y. Cryptocotyle lingua (Creplin) from the red fox Vulpes vulpes schrencki Kishida. Res bull Meguro Parasit Mus 1973; 7:
15-16. http://kiseichu.la.coocan.jp/publ/Res_Bull_MPM7_p1516.pdf

15. Gardner SL, Thew PT. Redescription of Cryptocotyle thapari Mcintosh, 1953 (Trematoda: Heterophyidae), in the River Otter Lutra longicaudis from Bolivia. Comp Parasitol 2006; 73: 20-23. https:// doi.org/10.1654/0001.1

16. Zander CD, Kollra HG, Antholz B, Meyer W, Westphal D. Smallsized euryhaline fish as intermediate hosts of the digenetic trematode Cryptocotyle concavum. Helgol Meeresunter 1984; 37: 433443. https://doi.org/10.1007/BF01989322

17. Wootton DM. The life history of Cryptocotyle concanum (Creplin, 1825) Fischoeder, 1903 (Trematoda: Heterophyidae). J Parasitol 1957; 43: 271-279. https://doi.org/10.2307/3274345

18. Issaitschikoff IM. Ciureana cryptocotyloides nov. sp. (a new bird trematode and its systematic position within the family Heterophyidae), Trudy Gosudarstv. Inst Eksper Vet 1923; 1: 155-158 (in Russian).

19. Skrjabin KI. Studies on the parasitic worms of carnivores II-IV. Trudy Gos Inst Exsp Vet 1923; 1: 67-71.

20. Kurochkin YV. Helminth fauna of the Caspian seal during its breeding season, Raboti Po Gelminthoogii K 80-etiyu Akademika K.I. Skrjabina. Academy of Science of USSR. Moscow, Russia. 1958, pp 188-194 (in Russian).

21. Jurachno MV. Ciureana delamurei sp. n. (Trematoda, Heterophyidae), a parasite of the northern fur seal. Parazitologiia 1987; 21: 752-754 (in Russian).

22. Dollfus RP, Timon-David J. Sur une larve de Distome, parasite têtards de Rana esculenta L., devenant adulte chez le chat domestique Felis catus L. domest. et le pigeon domestique Columba livia Gmel. Domest. CR Acad Sci Paris 1960; 250: 1909-1911 (in French).

23. Kamiya H, Obayashi M. Some helminths of the red fox, Vulpes vulpes schlencki Kishida, in Hokkaido, Japan, with a description of a new trematode, Massaliatrema yamashitai n. sp. Jpn J Vet Res 1975; 23: 60-68. http://hdl.handle.net/2115/2066

24. Tatonova YV, Besprozvannykh VV. Description of a new species, Cryptocotyle lata sp. nov., and discussion of the phylogenetic relationships in Opisthorchioidea. Parasitol Inter 2019: 72: 1-11 https:// doi.org/10.1016/j.parint.2019.101939

25. Hong EJ, Sim C, Chae JS, Kim HC, Park J, Choi KS, Yu DH, Yoo JG, Park BK. A horsehair worm, Gordius sp. (Nematomorpha: Gordiida), passed in a canine feces. Korean J Parasitol 2015; 53: 719-724. https://doi.org/10.3347/kjp.2015.53.6.719

26. Hoffman GL. Studies on the life cycle of Cryptocotyle concanum from the common sucker and experimentally in the chick. Proc North Dakota Acad Sci 1957; 11: 55-56.

27. Lee YI, Seo M, Chai JY. Intestinal flukes recovered from a herring gull, Larus argentatus, in the Republic of Korea, Korean J Parasitol 2020; 58: 81-86. https://doi.org/10.3347/kjp.2020.58.1.81 
